\title{
Synthesizing Results from Empirical Research on Engineering Design Process in Science Education: A Systematic Literature Review
}

\author{
Nanang Winarno ${ }^{1 *}$, Dadi Rusdiana ${ }^{2}$, Achmad Samsudin $^{2}$, Eko Susilowati ${ }^{3}$, Nur Jahan Ahmad ${ }^{4}$, \\ Ratih Mega Ayu Afifah ${ }^{5}$ \\ ${ }^{1}$ Department of Science Education, Universitas Pendidikan Indonesia, INDONESIA \\ 2 Department of Physics Education, Universitas Pendidikan Indonesia, INDONESIA \\ ${ }^{3}$ Department of Physics Education, Universitas Lambung Mangkurat, INDONESIA \\ ${ }^{4}$ School of Educational Studies, Universiti Sains Malaysia, MALAYSIA \\ ${ }^{5}$ SMA Taruna Bakti Bandung, INDONESIA
}

Received 16 June 2020 - Accepted 15 October 2020

\begin{abstract}
We reviewed 48 articles related to the engineering design process in science education published from 2010 to 2020. There are several previous literature review studies that analyzed the engineering design process in science education. However, we have not found any that investigates projects, discussed topics, as well as the benefits of the implementation of the engineering design process in science education. The research method used was a systematic literature review. This study analyzed the characteristics of the content based on year of publication, type of publications, countries that implement it, research approach, educational stage, and science content. The findings show that the projects used in the implementation of the engineering design processes in science education varied according to the discussed topics. The benefits of the implementation of the engineering design process in science education include cognitive benefits, procedural (skills) benefits, attitudinal benefits, and a combination of the three benefits.
\end{abstract}

Keywords: engineering design process, STEM education, science education, systematic reviews

\section{INTRODUCTION}

The implementation of Science, Technology, Engineering, and Mathematics (STEM) education through the engineering process has become more acknowledged in the field of education (Fan \& Yu, 2015). Banko, Grant, Jabot, McCormack, and O'Brien (2013) assert that the Next Generation Science Standards (NGSS) can be used as an alternative in the reform of science education as of now. The implementation of the NGSS emphasizes the integration between engineering and science learning in schools. In addition, engineering design in the implementation of NGSS can increase student motivation, creative thinking skills, and the ability to connect science with engineering. Moreover, the engineering design process is one of the crucial parts of STEM education (Lin, Hsiao, Chang, Chien \& Wu, 2018). Atman et al. (2007) state that engineering design is one of the competencies needed by students in engineering education. According to Nurtanto, Pardjono, Widarto, and Ramdani (2020), the engineering competence of students in vocational high schools can be improved by incorporating the engineering design process in their learning. Based on the results of these studies, the current K-12 reform of education emphasizes science education that is integrated with engineering design (Guzey, Ring-Whalen, Harwell, \& Peralta, 2017). Many countries have underlined the account of engineering in science education (Crotty et al., 2017). Furthermore, Guzey, Moore, Harwell, and Moreno (2016) also claims that the engineering design process is a new vision in science education. In addition, according to Lie, Aranda, Guzey, and Moore (2019), the engineering design process implemented in science learning can improve students' creative thinking and interdisciplinary abilities. Thus, the engineering design

(c) 2020 by the authors; licensee Modestum. This article is an open access article distributed under the terms and conditions of the Creative Commons Attribution License (http://creativecommons.org/licenses/by/4.0/). 


\section{Contribution to the literature}

- Previous literature review study focused on the implementation of the engineering design processes in the K-12 science classrooms. However, this study aims to investigate projects, topics, and benefits of the implementation of the engineering design process in science education. This research is not limited to K12 science classrooms, but this study investigates various levels of education, such as students, undergraduate or graduate students, and teachers.

- This research can be used as a reference for all stakeholders involved in science education.

- The results of this study can encourage science educators and other fields to implement the engineering design process in their learning.

process is not only applicable in engineering education, but it can also be implemented in science education.

Studies that integrate the engineering design process in science education have been carried out in several countries. Many of the aforementioned studies use various research approaches, such as mixed methods, quantitative, and qualitative. With the use of mixedmethod research approach, some studies aim to investigate: the influence of the engineering design process on students' situational interest (Dohn, 2013); students' perceptions of engineering and technology (Hammack, Ivey, Utley, \& High, 2015); efficacy (Maeng, Whitworth, Gonczi, Navy, \& Wheeler, 2017); content knowledge (Marulcu, \& Barnett, 2013); students' conceptions (Schnittka \& Bell, 2011; Dankenbring \& Capobianco, 2016); and students' ability in handling the complexity of a task (English, King, \& Smeed, 2016). In addition, some studies related to the engineering design process are also used to investigate some variables in the research. The aforementioned studies aim to investigate: the influence of the engineering design process on students' achievement and interest (Guzey, RingWhalen, Harwell, \& Peralta, 2017); students' understanding and self-efficacy (Zhou et al., 2017); as well as content knowledge, STEM conceptions, and engineering views (Aydin-Gunbatar, Tarkin-Celikkiran, Kutucu \& Ekiz-Kiran, 2018). Furthermore, Berland et al. (2013) attempt to examine the way students implement science and mathematics to their engineering work.

In a quantitative research approach, some studies aim to investigate: the influence of the engineering design process on problem-solving skills (Syukri, Halim, Mohtar \& Soewarno, 2018) and teachers' response (Pleasants, Olson, \& De La Cruz, 2020); the influence of the engineering design process on engineering content and attitudes towards STEM (Lie, Guzey, \& Moore, 2019); interest towards STEM subjects and career (Shahali, Halim, Rasul, Osman, \& Zulkifeli, 2016); curiosity and scientific disciplines (Ward, Lyden, Fitzallen, \& León de la Barra, 2016); as well as science attitudes, and science content knowledge (Wendell \& Rogers, 2013). In addition, Fan and Yu (2015) examines the influence of the STEM approach within engineering design practices on conceptual knowledge, higher-order thinking skills, and design project activity. $\mathrm{Yu}, \mathrm{Wu}$, and
Fan (2019) also look into the influence of the engineering design process on science knowledge and critical thinking within the delivered design product.

With the use of the qualitative research approach, some studies intend to analyze: the application of the engineering design process as well as its influence on students' understanding (Park, Park, \& Bates, 2016; Schnittka, 2012), on teachers' understandings (Mesutoglu, \& Baran, 2020), on reflective decisionmaking (Wendell, Wright, \& Paugh, 2017), on students' views of design (Lie, Aranda, Guzey, \& Moore, 2019), the classroom discourse (McFadden \& Roehrig, 2018), and on problem-solving skills (English, Hudson, \& Dawes, 2013). Some researches also examine the influence of the engineering design process on the generation of ideas and design thinking (English, Hudson, \& Dawes, 2012), on the subject matter and pedagogical content knowledge (Hynes, 2012), as well as on mindful planning and students' modeling practices (Bamberger \& Cahill, 2013). Capobianco, DeLisi, and Radloff (2018) also explain the development of elementary science teachers when implementing the engineering design process. Additionally, Chiu and Linn (2011) delve into how students integrate mathematics and science into their engineering design work.

In addition to using a mixed-method, quantitative, and qualitative research approach, we also found some studies related to the engineering design process that uses the systematic literature review (meta-analysis) method. One literature review study found is intended to summarize information on learnings with the engineering process through project-oriented capstone courses (Dutson, Todd, Magleby, \& Sorensen, 1997). In addition, Lammi, Denson, and Asunda (2018) review articles related to engineering design challenges in secondary school settings. A review of articles on the engineering design process in science learning is also carried out by Arık \& Topçu (2020). Their review investigates the steps of design in the engineering design process that are used for learning. Although we have managed to find literature reviews that analyze the implementation of the engineering design process in science education. However, we have not found any previous literature review studies that aim to investigate which projects and topics are used in the 
implementation of the engineering design process in science education. Furthermore, studies investigating the benefits of implementing the engineering design process in science education have also not been carried out by previous researchers.

Based on this explanation, there have been innovations in education that integrate the engineering design process in science education. However, students still experience difficulties in connecting the design projects that they develop with Science (Chao et al., 2017). Berland et al. (2013) also state that although students are able to apply science and mathematics to their engineering projects, the implementation in itself is still rather inconsistent. In addition to students, teachers also claim that teaching science using the engineering design process is challenging and, still, leads to several problems (Capobianco, 2011). These problems are most probably caused by the fact that engineering design is a new, unfamiliar concept to some teachers. Due to the newness of engineering design, science teachers may feel challenged when implementing engineering in science education (Guzey, Harwell, Moreno, Peralta, \& Moore, 2016). In addition, science learning, as of now, still encounters several problems in various countries. The problems in learning science are that students regard science as difficult, less interesting, and have too many formulas (Zhang \& He, 2012; Winarno, Rusdiana, Riandi, Susilowati, \& Afifah, 2020). Ogunkola and Samuel (2011) also explain that students' perceptions of science lessons are abstract; this arises in spite of the fact that science lessons are closely related to everyday life so that students can observe science directly in their environment. Furthermore, according to Sun, Wang, Xie, \& Boon (2014), they argue that the implementation of science learning in schools still does not meet the expected standards; that said, there is a need for learning innovations to improve the quality of learning.

From the aforementioned explanation, it can be concluded that the implementation of the engineering design process in science education has not achieved its expected merit. This is mainly due to the implementation process in the field that is still faced with challenges (Berland, Martin, Ko, Peacock, Rudolph, \& Gulobski, 2013; Capobianco, 2011; Chao et al., 2017) as the engineering design process is a new, unfamiliar concept to most science teachers (Guzey, Harwell, Moreno, Peralta, \& Moore, 2016). According to Dankenbring and Capobianco (2016), the current reform of education is based on the integration of science learnings through engineering practices. Based on these problems, learning innovations that are based on the engineering design process are expected to be an alternative solution to solve various problems in science education.

This research explains the characteristics of its content, such as year of publication, type of publication, countries that implement the engineering design process, research approach, educational stage, and science content. The purpose of analyzing the characteristics of the content is to provide an overview of the articles analyzed in this study. Furthermore, we also investigated which projects and topics are used in previous studies in implementing the engineering design process in science education (Science, Physics, Chemistry, and Biology). In addition, the results of this study can provide a comprehensive explanation for stakeholders in the field of science education who will implement the engineering design process into their learning. For example, to teach the topic of "energy" by using the engineering design process, we will mention some alternative projects that are suitable for use on the topic of energy based on the results of the previous studies. Furthermore, this study also explains the benefits of the engineering design process in science education. The elaboration of the benefits of the engineering design process in science education is based on cognitive, procedural/skills, attitudinal benefits, and a combination of the aforementioned three benefits. Therefore, the results of this study are not only useful for stakeholders in the field of science education who will implement the engineering design process, but also for future researchers. We served the data in the form of tables so that readers will find it easier to comprehend. The results of previous research reveal that learning with the engineering design process had a positive effect on students (Kim, Oliver, \& Kim, 2019).

Thus, a literature review study that discusses the engineering design process in science education is essential to be carried out. The results of this study are expected to be beneficial as reference for all stakeholders involved in science education, especially teachers, lecturers, or future researchers. In addition, the engineering design process can be used as an alternative learning approach in science education. The aim of this study was to review 48 articles related to the engineering design in science education that are published from 2010 to 2020. There are three research questions used to guide the process of this study:

1. How is the distribution of research based on the characteristics of the content?

2. What are the projects and discussed topics in the implementation of the engineering design process in science education?

3. What are the benefits of the engineering design process in science education?

\section{METHODS}

\section{Research Design}

The research method used in this study was a systematic literature review (Petticrew \& Roberts, 2008). We chose 48 articles from highly-regarded journals published from 2010 to 2020. All journals chosen are indexed by Scopus and Web of Science (WoS). Scopus 
Table 1. The stages of the review process

\begin{tabular}{lll}
\hline NO & Stages & Actions \\
\hline 1 & $\begin{array}{l}\text { Determining the } \\
\text { research questions }\end{array}$ & $\begin{array}{l}\text { Discussing the research questions among the writers based on the research theme that is the } \\
\text { engineering design process in science education }\end{array}$
\end{tabular}

2 Determining the criteria We are determining the criteria of the articles to be shortlisted for review. The articles must be related to the engineering design process in science education and must be indexed by Scopus and Web of Science or just Scopus. The articles selected to be indexed by Scopus have at least a quartile 2 (Q2) category so that the quality of the articles is classified as excellent. In addition, we selected articles that are in English only.

3 Producing the protocol Generating a research framework for each section, starting from the title, introduction, method, for the review results, discussion, and conclusion

4 Searching, screening, Looking for journals from the highly-regarded publishers with the following keywords: and selecting engineering design process, engineering design, engineering design in science education, or STEM through the engineering design process.

We were shortlisting articles based on the predetermined criteria. All articles must be published by international highly-regarded journals and related to the engineering design process in science education. If the articles did not meet these criteria, they were exempted from review. Discussing the validity and the reliability of the articles among authors Choosing articles that are relevant to the engineering design process in science education

$5 \quad$ Analyzing and interpreting

6 Producing the article

7 Dissemination
Reading and understanding the content of the chosen articles

Analyzing the chosen articles for review according to the predetermined research questions Interpreting the results of the analysis in the form of tables and figures

Discussing the results of the analysis as well as synthesizing it with the results of the previous studies

Writing a literature review article following the intended journal's format

Publishing the article to international journals and Web of Science (WoS) were used as the basis for selecting articles because they are both reputable journal indexers. The articles published on Scopus and the Web of Science (WoS) are also of good quality and can be accounted for. This study aims to review 48 articles related to engineering design in science education.

\section{Research Procedure}

In carrying out this study, there were seven stages of the review process: (1) Determining the research questions; (2) Determining the criteria; (3) Producing the protocol for the review; (4) Searching, screening, and selecting; (5) Analyzing and interpreting; (6) Producing the article; and (7) Dissemination (Bennett, Lubben, Hogarth, \& Campbell, 2005; Borrego, Foster, \& Froyd. 2014). The stages of the review process are elaborated in Table 1.

\section{Data Collection}

The articles chosen for review were published from January 2010 to April 2020. The highly-regarded publishers that were chosen are Taylor \& Francis, Springer, Wiley, Cambridge, Elsevier, Emerald, Oxford, Sage, etc. We also looked for articles directly on the website of international journals. The keywords used were: "STEM approach" "STEM education", "engineering design", "engineering design process", "engineering design in science education" or "STEM through the engineering design process". There were about 393 articles found. However, only 48 articles met our research criteria. The number of articles is symbolized by the letter " $\mathrm{f}$ " in the table. The shortlisted journals for review are to be found in Table 2.

From Table 2, it shows that out of 19 international journals, 15 journals are indexed by both Scopus and WoS, and the remaining four are indexed by Scopus only. Out of the 48 chosen articles, 38 articles are indexed by both Scopus and WoS, and the remaining ten are indexed by Scopus only. All chosen journals can be found in Scimago Journal \& Country Rank (Scimagojr.com). Scimago Journal \& Country Rank states that the journals have high $\mathrm{H}$-index. Also, most of the journals are indexed by Web of Science based on Clarivate Analytics. Therefore, it can be concluded that the articles chosen for this study are of good quality.

\section{Data Analysis}

The data obtained in this study were analyzed with a descriptive approach. We classified the data in the form of tables and figures based on the predetermined research framework. The data was then discussed comprehensively and synthesized with the previous research. The focus of this study is to investigate the distribution of research based on the characteristics of the content, projects and discussed topics, and the benefits of the engineering design process in science education. 
Table 2. The shortlisted articles for review

\begin{tabular}{|c|c|c|c|c|c|}
\hline No & Name of journal & $\mathrm{f}$ & $(\%)$ & Indexed By & $\begin{array}{c}\text { H-Index } \\
2019 \text { (SJR) }\end{array}$ \\
\hline 1 & Journal of Research in Science Teaching & 2 & 04.17 & Scopus (Q1) \& WoS & 121 \\
\hline 2 & Science Education & 2 & 04.17 & Scopus (Q1) \& WoS & 108 \\
\hline 3 & International Journal of Science Education & 6 & 12.50 & Scopus (Q1) \& WoS & 102 \\
\hline 4 & Journal of Engineering Education & 3 & 06.25 & Scopus (Q1) \& WoS & 101 \\
\hline 5 & Journal of Educational Research & 1 & 02.08 & Scopus (Q1) \& WoS & 71 \\
\hline 6 & Instructional Science & 1 & 02.08 & Scopus (Q1) \& WoS & 68 \\
\hline 7 & Journal of Science Education and Technology & 6 & 12.50 & Scopus (Q1) \& WoS & 56 \\
\hline 8 & Research Science Education & 3 & 06.25 & Scopus (Q1) \& WoS & 50 \\
\hline 9 & European Journal of Engineering Education & 1 & 02.08 & Scopus (Q1) \& WoS & 41 \\
\hline 10 & Journal of Science Teacher Education & 1 & 02.08 & Scopus (Q1) \& WoS & 40 \\
\hline 11 & Chemistry Education Research and Practice & 1 & 02.08 & Scopus (Q1) \& WoS & 40 \\
\hline 12 & International Journal of Technology and Design Education & 3 & 06.25 & Scopus (Q1) \& WoS & 37 \\
\hline 13 & International Journal of Science and Mathematics Education & 6 & 12.50 & Scopus (Q1) \& WoS & 35 \\
\hline 14 & Computer Applications in Engineering Education & 1 & 02.08 & Scopus (Q1) \& WoS & 26 \\
\hline 15 & Journal of Baltic Science Education & 1 & 02.08 & Scopus (Q2) \& WoS & 14 \\
\hline 16 & Journal of Pre-College Engineering Education Research & 7 & 14.58 & Scopus (Q1) & 8 \\
\hline 17 & Jurnal Pendidikan IPA Indonesia (Indonesian Journal of Science Education) & 1 & 02.08 & Scopus (Q2) & 12 \\
\hline 18 & Eurasia Journal of Mathematics Science and Technology Education & 1 & 02.08 & Scopus (Q2) & 31 \\
\hline \multirow[t]{2}{*}{19} & Australasian Journal of Engineering Education & 1 & 02.08 & Scopus (Q2) & 5 \\
\hline & Total & 48 & 100 & & \\
\hline
\end{tabular}

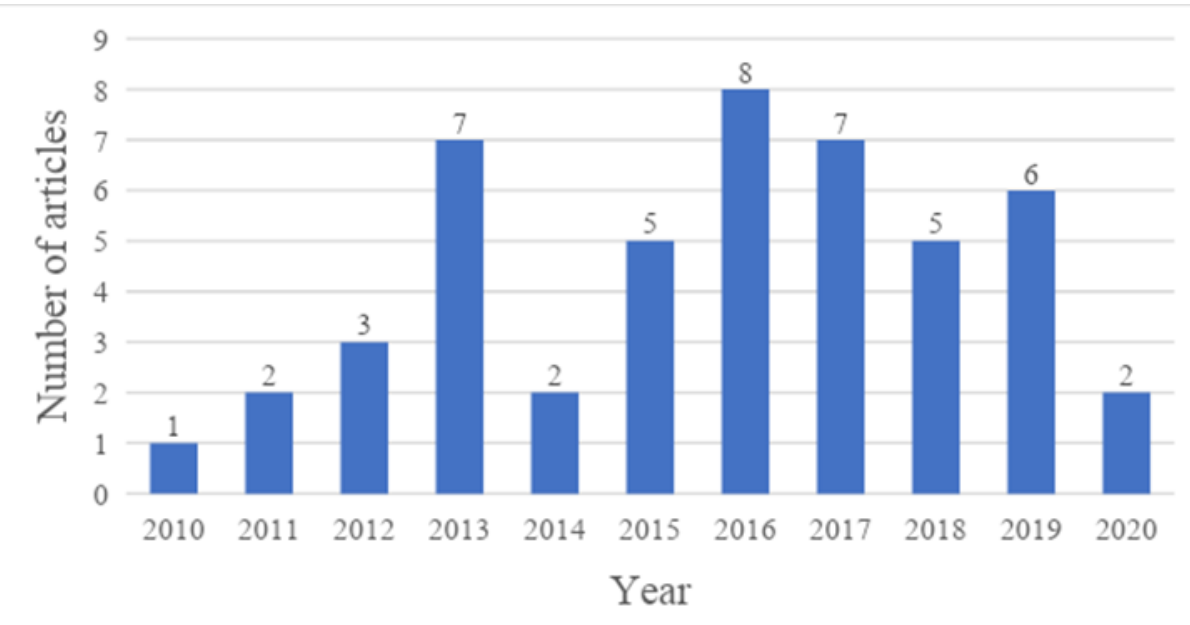

Figure 1. The distribution of research based on year of publication

\section{RESULTS}

\section{Research Question 1: How is the Distribution of Research Based on the Characteristics of the Content?}

The distribution of research is divided based on the following characteristics: year of publication, type of publication, countries that implement the engineering design process, research approach, educational stage, and science content.

\section{The distribution of research based on year of publication}

The distribution of research chosen for review ranged from 2010 to 2020 . The complete data can be seen in Figure 1.

From Figure 1, it can be seen that the distribution varied each year: 1 article $(02.08 \%)$ was published in
2010; 2 articles $(04.17 \%)$ were published in 2011; 3 articles $(06.25 \%)$ were published in 2012; 7 articles $(14.58 \%)$ were published in 2013; 2 articles $(04.17 \%)$ were published in $2014 ; 5$ articles $(10.42 \%)$ were published in 2015; 8 articles (16.67\%) were published in 2016; 7 articles (14.58\%) were published in 2017; 5 articles (10.42\%) were published in 2018; 6 articles $(12.50 \%)$ were published in 2019; and 2 articles $(04.17 \%)$ were published in 2020 . In conclusion, the highest number of reviewed articles was published in 2016, and the lowest number of reviewed articles was published in 2010.

\section{The distribution of research based on the type of publication}

The distribution of research based on the type of publication is divided into journal, proceeding, and thesis. The data can be seen in Table 3 . 
Table 3. The distribution of research based on the type of publication

\begin{tabular}{llcc}
\hline NO & Type of Publications & f & $\%$ \\
\hline 1 & Journal & 48 & 100 \\
2 & Proceeding & 0 & 0 \\
3 & Thesis & 0 & 0 \\
\hline Total & & 48 & 100 \\
\hline
\end{tabular}

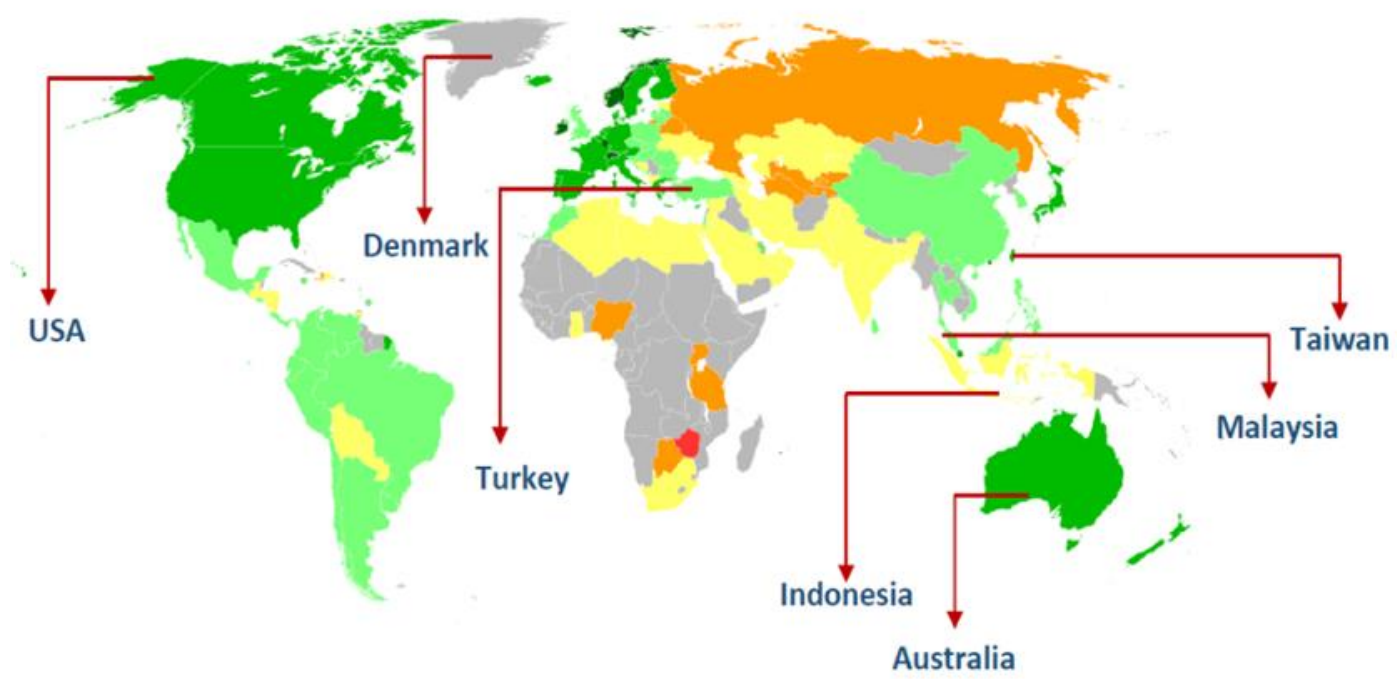

Figure 2. The map of the countries and regions that implement the engineering design process in science education

Table 4. The distribution of research based on the countries that implement the engineering design process in science education

\begin{tabular}{lccll}
\hline No & Country & f & $(\%)$ & E.g., (only first author cited) \\
\hline 1 & USA & 34 & 70.83 & $\begin{array}{l}\text { Apedoe (2013); Bamberger (2013); Berland (2013); Berland (2014); Berland (2016); Capobianco } \\
\text { (2014); Capobianco (2018); Chao (2017); Chase (2019); Chiu (2011); Crotty (2017); Dankenbring }\end{array}$ \\
& & & $\begin{array}{l}\text { (2016); Egbue (2015); Guzey (2017); Hammack (2015); Hertel (2017); Hynes (2012); Johnston (2019); } \\
\text { Lie (2019); Lie (2019); Maeng (2017); Marulcu (2013); McFadden (2018); Park (2016); Pleasants } \\
\text { (2020); Schnittka (2011); Schnittka (2012); Valtorta (2015); Wendel (2010); Wendell (2013); Wendell }\end{array}$ \\
& & & & \\
& & & & \\
& & &
\end{tabular}

Based on Table 3, it can be seen that all articles for review were chosen from 48 international journals $(100 \%)$. Although many articles on the engineering design process in science education have been published in proceedings and theses, we did not choose the articles from these proceedings and theses. We aim that the articles selected for review are articles of excellent quality and can be accounted for. In addition, the selection of articles from journals indexed by Scopus or Web of Science (WoS) is more stringent and has been through a peer review. Based on the given data, it can be concluded that the articles chosen for this study are of good repute and quality.
The distribution of research based on countries and regions that implement the engineering design process in science education

The data of the countries and regions that implement the engineering design process in science education were obtained from the affiliation of the writer of the chosen articles. The complete data can be seen in Figure 2.

Based on Figure 2, the countries that implement the engineering design process in science education are the United States of America (USA), Australia, Taiwan, Turkey, Malaysia, Denmark, and Indonesia. The distribution of research can be seen in Table 4. 
Table 5. Research Approach

\begin{tabular}{llcc}
\hline No & Research Approach & f & $(\%)$ \\
\hline 1 & Quantitative & 15 & 31.25 \\
2 & Qualitative & 20 & 41.67 \\
3 & Mixed Methods & 13 & 27.08 \\
\hline Total & & 48 & 100 \\
\hline
\end{tabular}

Table 6. The distribution of research based on the educational stage

\begin{tabular}{llccc}
\hline Participants/sample & Educational Stage (Level) & f & $(\%)$ & Total (\%) \\
\hline Student & Elementary/Primary school & 10 & 20.83 & 31.25 \\
& Middle school & 15 & 14.58 & $37(77.08)$ \\
& High school & 7 & 04.17 & 04.17 \\
& University/undergraduate & 2 & 2 & 02.08 \\
\hline Teacher & Elementary and middle school & 1 & 12.50 & $10(20.83)$ \\
& Middle and high school & 6 & 08.33 & 02.08 \\
\hline Others & Elementary & 4 & $1(02.08)$ \\
\hline Total & Middle School & 1 & 00 & $48(100)$ \\
\hline
\end{tabular}

Based on Table 4, it can be seen that the United States of America had the highest number of articles with 34 articles $(70.83 \%)$. Denmark and Indonesia were the lowest in the number of articles with 1 article (02.08\%), respectively. From the data, it can be concluded that there are very few countries that implement the engineering design process in science education.

\section{The distribution of research based on the research approach}

The research approach was determined by the research method used in the articles. The complete data can be seen in Table 5 .

Based on Table 5, it can be seen that there were three research approaches: quantitative, qualitative, and mixed methods. The most used research approach was qualitative with 20 articles (41.67\%), and the least used approach was mixed methods with 13 articles (27.08\%).

\section{The distribution of research based on the educational stage}

The sample of participants in the articles was analyzed to determine the distribution of research based on the educational stage. This aims to provide an overview of the distribution of previous studies related to engineering design process in science education based on the level of education. Elementary school level consists of students aged around 6-12 years. Middle school level consists of students who have graduated from elementary school within an age of around 12-15 years. High school level consists of students who have graduated from middle school within an age of 15-18 years. Undergraduate level consists of students who have graduated from high school and continue their studies to university level within the age of around 1822 years. Meanwhile, graduate students are students who have graduated from university level around the age of 22 years or more. The complete data can be seen in Table 6.

Based on Table 6, it can be seen that there were 37 articles $(77.08 \%)$ which sample or participant consisted of students; 10 articles $(20.83 \%)$ with teachers as the sample or participants; and 1 article $(02.08 \%)$ with undergraduate/graduate students as the sample of participants. The distribution of research based on the educational stage was found the highest in middle school students with 15 articles (31.25\%). The lowest came from undergraduate/graduate students with only 1 article $(02.08 \%)$. From the data, it can be concluded that the engineering design process is implemented in science education of various educational stages (level). However, the implementation in the undergraduate/graduate level is still rather scarce when compared to the elementary school, middle school, and high school levels.

\section{The distribution of research based on science content}

This study divides the science content into 5: Science, Physics, Biology, Chemistry, and the integration of science with other subjects. The selection of articles containing the integration of science with other subjects aims to investigate fields other than science that use one of the topics of science in their research. The discussion of the results of this study is broader and more comprehensive because interdisciplinary fields related to science are also described in this study. The science content was divided based on school subjects or research topics. The complete data can be seen in Table 7 .

From Table 7, it can be seen that the implementation of the engineering design process was mostly found in the subject of science, with the least found in the integration of science with other subjects. Based on the data, it can be concluded that the engineering design process is implemented in Science, Physics, Biology, 
Table 7. The distribution of research based on the science content

\begin{tabular}{lllc}
\hline Science Content & Information & $\mathrm{f}$ & $(\%)$ \\
\hline Science & - & 18 & 37.50 \\
Physics & - & 17 & 35.42 \\
Biology & - & 3 & 06.25 \\
Chemistry & - & 3 & 06.25 \\
\hline The integration of & Science and Mathematics & 4 & 08.33 \\
science with other & Physics, Biology, and Chemistry & 1 & 02.08 \\
subjects & Science, Mathematics, and Computers & 1 & 02.08 \\
& Physics and Biology & 1 & 02.08 \\
\hline Total & & & 48 \\
\hline
\end{tabular}

Table 8. The projects and discussed topics in science

\begin{tabular}{llll}
\hline No & Project & Topic & $\begin{array}{l}\text { E.g., (only first author } \\
\text { cited) }\end{array}$ \\
\hline 1. & - A better play dough. & Capobianco (2014) \\
& - Birds busting a beat & - Simple machines & \\
& - Crawler creations (Lego crawler) & - Forces affect the motion and speed & Capobianco (2018) \\
2. & $\begin{array}{l}\text { Musical instrument, door alarm, compost column, and } \\
\text { solar panel tracker }\end{array}$ & Energy and matter & Dankenbring (2016)
\end{tabular}
picnic table during noontime in both the summer and winter.

4. A catapult, produce the most carbon dioxide, to measure The topic is not explained

Dohn (2013) salt content in water, wind generator, wind-powered vehicle, vehicle and a glider that can soar

5. Bridge construction

6. The earthquake design

7. Teacher's engineering talk

8. Alarm circuits, cleaning an oil Spill, evaluating a landscape, plant packages electricity, the effects of oil spills on ecosystems, erosion and landforms, plants and functions of packages

9. Nesting platforms

10. - Circuit building, instrument, bridge, tower, submersible, roller coaster, and rocket

- Water filter, rover, watershed, ocean floor model, ways to contain/clean up oil spills, hurricane-proof building, and weather instrument environmental science

- Gardens, ecosystems, and habitats

11. A mining extraction tool

12. Wind turbine

13. Building, road, dam, or other civil structure

14. Building a submarine

15. Musical instrument, model house, people mover, an animal model

16. Bridges, water filters, maglev vehicles, knee braces, windmills, pollinators, knee Braces, circuits

17. Automatic plant watering device

18. A three-dimensional model of the toy

Measurements

Earthquake

Genetically modified organisms

Electricity, the effects of oil spills on ecosystems, erosion and landforms, plants and functions of a package

\section{Ecology}

Lie (2019)

- Electricity, simple machines, sound, and force, motion, and energy

- Human impacts on the environment, space, erosion, watersheds, oceans, weather

- Ecosystems, homeostasis, and plants

Renewable and non-renewable resources

Energy

A chemical technology

Fluid

Simple machines

English (2012)

English (2016)

Guzey (2017)

Hertel (2017)

Maeng (2017)

Energy

McFadden (2018)

Mesutoglu (2020)

Pleasants (2020)

Siew (2016)

Wendell (2013)

Wendell (2017)

Energy transfer

The topic is not explained
Wendell (2019)

$\mathrm{Yu}$ (2019)
Chemistry, and the integration of science with other subjects.

\section{Research Question 2: What are the Projects and Discussed Topics in the Implementation of the Engineering Design Process in Science Education?}

The design projects and discussed topics in the implementation of the engineering design process were mostly found in Science, Physics, Biology, Chemistry, and the integration of science with other subjects.

\section{The projects and topics in science}

The data of the projects and discussed topics in science can be seen in Table 8 .

Table 8 shows that there were 18 projects related to the implementation of the engineering design process in 
Table 9. The projects and discussed topics in Physics

\begin{tabular}{|c|c|c|c|}
\hline No & Project & Topic & $\begin{array}{l}\text { E.g., (only first author } \\
\text { cited) }\end{array}$ \\
\hline 1. & Wind Turbine & Energy & Bamberger (2013) \\
\hline 2. & Energy-efficient home design & Energy/Heat transfer & Chao (2017) \\
\hline 3. & Cantilevers & Center of mass & Chase (2019) \\
\hline 4. & Electric vehicle electric vehicles' batteries & Sustainability and alternative energy & Egbue (2015) \\
\hline 5. & Catapult & Simple machines & English (2013) \\
\hline 6. & Virtual computer-aided design and simulation & $\begin{array}{l}\text { Mechanics lever scales, Cam toy, } \\
\text { Gear wheeled range finder, Gear set. }\end{array}$ & Fan (2015) \\
\hline 7. & Optical instrument & Mirror and lens & King (2016) \\
\hline 8. & Toy crane & Simple machines & Korur (2015) \\
\hline 9. & People Mover & Simple machines & Marulcu (2013) \\
\hline 10. & The save the penguins engineering design & Thermal energy and heat transfer & Schnittka (2011) \\
\hline 11. & The save the penguins engineering design & Thermal energy and heat transfer & Schnittka (2012) \\
\hline 12. & Solar car & Energy & Shahali (2016) \\
\hline 13. & Free electricity energy & Electricity and magnetism & Syukri (2018) \\
\hline 14. & Camera & Optics & Valtorta (2015) \\
\hline 15. & $\begin{array}{l}\text { A stable, quiet, thermally } \\
\text { comfortable model house. }\end{array}$ & $\begin{array}{l}\text { Strength, elastic modulus, density, } \\
\text { heat capacity, thermal conductivity, } \\
\text { and expansion. }\end{array}$ & Wendell (2010) \\
\hline 16. & $\begin{array}{l}\text { A Cost-effective rooftop solar power system for their } \\
\text { home buildings. }\end{array}$ & Energy & Xie (2018) \\
\hline 17. & A foil boat, trebuchet, fan boat, and marshmallow tower, & Energy transfer & Zhou (2017) \\
\hline
\end{tabular}

Table 10. The projects and discussed topics in Biology

\begin{tabular}{|c|c|c|c|}
\hline No & Project & Topic & $\begin{array}{l}\text { E.g., (only first author } \\
\text { cited) }\end{array}$ \\
\hline 1. & $\begin{array}{l}\text { A Simple hydroponic system, a fish fitness-testing device, } \\
\text { a barrier that effectively reduces the cross-contamination } \\
\text { of non-GMO cornfields from GMO cornfields. }\end{array}$ & $\begin{array}{l}\text { Plants and Space, Fit Fish, } \\
\text { Genetically Modified Organisms }\end{array}$ & Crotty (2017) \\
\hline 2. & Engineering talk & The topic is not explained & Johnston (2019) \\
\hline 3. & $\begin{array}{l}\text { Explore cells, consider the relationship of the structure } \\
\text { and function of DNA, basic heredity patterns found in } \\
\text { nature, study sexual and asexual reproduction. }\end{array}$ & Genetically modified organisms & Lie (2019) \\
\hline
\end{tabular}

Table 11. The projects and discussed topics in Chemistry

No Project

1. Airbag, chemical reactions project

2. Cold-pack design, keeping apples from turning brown, devising homemade indicators and $\mathrm{pH}$ strips, Topic E.g., (only first author cited)

Force, motion, position and velocity, Chiu (2011) climate change, energy use, and greenhouse gases. instruments for measuring the $\mathrm{CO}_{2}$ level in an aquarium, electrochemistry, Aqueous solution, and building voltaic cells.

Chemical reactions and energy, Rate Aydin-Gunbatar (2018) of chemical reaction, acids and bases, and chemical equilibrium,

3. Airplane, popcorn challenge, rocket body to attach to Chemicals Hammack (2015) their film canisters

science. It can be concluded that the choice of projects varied on the discussed topic.

\section{The projects and topics in Physics}

The data of the projects and discussed topics in Physics can be seen in Table 9.

Table 9 shows that there were 17 projects related to the implementation of the engineering design process in Physics. It can be concluded that the choice of projects varied depending on the discussed topic.

\section{The projects and topics in Biology}

The data of the projects and discussed topics in Biology can be seen in Table 10.

Table 10 shows that there were three projects related to the implementation of the engineering design process in Biology. It can be concluded that the choice of projects varied depending on the discussed topic.

\section{The projects and topics in Chemistry}

The data of the projects and discussed topics in Chemistry can be seen in Table 11. 
Table 12. The projects and discussed topics in science integrated with other subjects

\begin{tabular}{|c|c|c|c|c|}
\hline No & Project & Topic & $\begin{array}{l}\text { E.g., (only first } \\
\text { author cited) }\end{array}$ & Science Content \\
\hline 1. & Wind Turbine & Energy & Berland (2013) & Science and math \\
\hline 2. & $\begin{array}{l}\text { A Pinhole camera, a system to } \\
\text { take aerial images, wind } \\
\text { turbines, robotic vehicles, and } \\
\text { construction helmets. }\end{array}$ & $\begin{array}{l}\text { Power equations and energy } \\
\text { transformation (Science) } \\
\text { Converting between different units of } \\
\text { measurement (Math) }\end{array}$ & $\begin{array}{l}\text { Berland (2014); } \\
\text { Berland (2016) }\end{array}$ & Science and math \\
\hline 3. & $\begin{array}{l}\text { A model ear, sound detection, } \\
\text { and applied them to the } \\
\text { operation of the vocal tract. }\end{array}$ & Sound wave & Ward (2016) & Physics, Biology \\
\hline 4. & The earthquake design task & $\begin{array}{l}\text { Genetics (Biology), projectile motion } \\
\text { (Physics), chemical energy (Chemistry) }\end{array}$ & Apedoe (2013) & $\begin{array}{l}\text { Physics, Biology } \\
\text { Chemistry }\end{array}$ \\
\hline 5. & $\begin{array}{l}\text { Spatula design } \\
\text { Wheelchair design }\end{array}$ & The topic is not explained & Hynes (2012) & $\begin{array}{l}\text { Science, Mathematics, } \\
\text { Science and Mathematics, } \\
\text { General, computer }\end{array}$ \\
\hline 6. & Making of a clay boat & Concept of volume & Park (2016) & Science and Mathematics \\
\hline
\end{tabular}

Table 13. The distribution of research based on the cognitive benefits

\begin{tabular}{llll}
\hline No & Benefits & E.g., (only first author cited) & f \\
\hline 1 & Improving students' content knowledge/student's & Chao (2017); Marulcu (2013); Park (2016); Dankenbring & 6 \\
& achievement & (2016); Aydin-Gunbatar (2018); Guzey (2017) \\
2 & Improving science teachers' understanding & Mesutoglu (2020) & Schnittka (2011) \\
3 & Effective for conceptual change & Crotty (2017) \\
4 & $\begin{array}{l}\text { Introducing engineering at the beginning of the lesson } \\
\text { resulted in higher students' achievements compared to }\end{array}$ & \\
& introducing engineering only at the end of the lesson & \\
\hline & Total & & 1 \\
\hline
\end{tabular}

Table 11 shows that there were 3 projects related to the implementation of the engineering design process in Chemistry. It can be concluded that the choice of projects varied depending on the discussed topic.

\section{The projects and topics in science integrated with other subjects}

The data of the projects and discussed topics in science integrated with other subjects can be seen in Table 12.

Table 12 shows that there were 6 projects related to the implementation of the engineering design process in science integrated with other subjects. It can be concluded that the choice of projects varied depending on the discussed topic.

\section{Research Question 3: What are the Benefits of the Engineering Design Process in Science Education?}

This study also examined the benefits of the engineering design process in science education. According to Martín-Páez, Aguilera, Perales-Palacios, and Vílchez-González (2019), the benefits of a learning approach can be classified into cognitive benefits, procedural benefits (skills benefits), and attitudinal benefits. In this study, we classified them into four categories of cognitive benefits, procedural benefits (skills benefits), attitudinal benefits, and the combination of the three aforementioned benefits. There is an addition of one category: the combination of the three aforementioned benefits because this study also incorporated interdisciplinary research related to science.

\section{Cognitive benefits}

Cognitive benefits are those that are based on empirical factual knowledge. The complete data of the cognitive benefits of the engineering design process can be found in Table 13.

Table 13 shows that the cognitive benefits of the engineering design process were found in 9 articles. Most articles claimed that the engineering design process improved students' content knowledge. It can be concluded that the implementation of the engineering design process in science education may improve students' content knowledge, science teachers' understanding, and is effective for conceptual change.

\section{Procedural Benefits (Skills Benefits)}

Procedural/skills benefits are proficiency in a specific field. The complete data of the procedural benefits of the engineering design process can be found in Table 14.

Table 14 shows that the procedural benefits (skills benefits) of the engineering design process were found in 21 articles. Most articles claimed that the engineering design process could integrate engineering with science learning. It can be concluded that the implementation of the engineering design process in science education may improve students' content knowledge, science teachers' 
Table 14. The distribution of research based on the procedural benefits (skills benefits)

\begin{tabular}{|c|c|c|c|}
\hline No & Benefits & E.g., (only first author cited) & $\mathrm{f}$ \\
\hline 1 & Encourage mindful planning and students' modeling practices. & Bamberger (2013) & 1 \\
\hline 2 & $\begin{array}{l}\text { A better understanding of engineering design aspects was achieved when } \\
\text { using qualitative method compared to quantitative }\end{array}$ & Berland (2014) & 1 \\
\hline 3 & Improved students' thinking & Capobianco (2018) & 1 \\
\hline 4 & Improved students' attention to learning and transfer situation & Chase (2019) & 1 \\
\hline 5 & Better ability in integrating engineering and science learning & $\begin{array}{l}\text { Chiu (2011); Berland (2013); Valtorta } \\
\text { (2015); Berland (2016) }\end{array}$ & 4 \\
\hline 6 & $\begin{array}{l}\text { Effective monitoring factor for the generation of ideas and students' } \\
\text { reasoning }\end{array}$ & English (2012) & 1 \\
\hline 7 & Improved students' problem-solving skills & English (2013); Syukri (2018) & 2 \\
\hline 8 & Improved students' ability in handling the complexity of a task & English (2016) & 1 \\
\hline 9 & Supported STEM integration & Johnston (2019) & 1 \\
\hline 10 & Useful for structuring stages of design, construction, and redesign & King (2016) & 1 \\
\hline 11 & Improved students' level of ability in various subjects & Schnittka (2012) & 1 \\
\hline 12 & $\begin{array}{l}\text { Improved materials selection tasks, completion of their workbooks, and the } \\
\text { workbook's reflective record-keeping tasks }\end{array}$ & Wendel (2010) & 1 \\
\hline 13 & Improvement in sophisticated discourse & Wendell (2017); McFadden (2018) & 2 \\
\hline \multirow[t]{2}{*}{14} & Improved the ability in designing projects & Xie (2018); Lie (2019); Apedoe (2013) & 3 \\
\hline & Total & & 21 \\
\hline
\end{tabular}

Table 15. The distribution of research based on the attitudinal benefits

\begin{tabular}{|c|c|c|c|}
\hline No & Benefits & E.g., (only first author cited) & $\mathrm{f}$ \\
\hline 1 & $\begin{array}{l}\text { Improved participation, student interest and self-concept in engineering and } \\
\text { science }\end{array}$ & Capobianco (2014) & 1 \\
\hline 2 & Stimulating students' situational interest & Dohn (2013) & 1 \\
\hline 3 & Impacted positively on students' perceptions of engineering and technology & Hammack (2015) & 1 \\
\hline 4 & Attitudes towards engineering & Lie (2019) & 1 \\
\hline 5 & Supported efficacy & Maeng (2017) & 1 \\
\hline 6 & $\begin{array}{l}\text { Improved teachers' views on the implementation of the engineering design } \\
\text { process in their teachings }\end{array}$ & Pleasants (2020) & 1 \\
\hline \multirow[t]{2}{*}{7} & Improved interest in STEM subjects and career & Shahali (2016) & 1 \\
\hline & Total & & 7 \\
\hline
\end{tabular}

understanding, and is effective for improving various students' skills.

\section{Attitudinal benefits}

Attitudinal benefits are benefits related to behavior or actions based on one's stance. The complete data of the attitudinal benefits of the engineering design process can be found in Table 15.

Table 15 shows that the attitudinal benefits of the engineering design process were found in 7 articles. It can be concluded that the implementation of the engineering design process in science education may result in various attitudinal benefits.

\section{Combination of cognitive, procedural/skills, and attitudinal benefits}

The combination of cognitive, procedural/skills, and attitudinal benefits is the benefit obtained by more than one cognitive, procedural/skills, and/or attitudinal benefits. Thus, this section measures more than one variable from the three categories. The complete data of the combination of cognitive, procedural/skills, and attitudinal benefits of the engineering design process can be found in Table 16.
Table 16 shows that the combination of cognitive, procedural/skills, and attitudinal benefits of the engineering design process were found in 11 articles. Most articles claimed that the engineering design process improved scientific knowledge and reasoning. Based on the data, it can be concluded that the implementation of the engineering design process in science education may result in different combinations of cognitive, procedural/skills, and attitudinal benefits.

\section{DISCUSSION}

This study aims to review 48 articles from international highly-regarded journals related to the engineering design process in science education. The focus of this study is to investigate the distribution of research based on the characteristics of the content, projects, and discussed topics, and benefits of the engineering design process in science education. A literature review study that examines the distribution of research based on the characteristics of the content is in line with several previous studies (Deveci \& Çepni, 2017). Martín-Páez, Aguilera, Perales-Palacios, and Vílchez-González (2019) which state that the analysis of the distribution of research based on the general 
Table 16. The distribution of research based on the attitudinal benefits

\begin{tabular}{|c|c|c|c|c|}
\hline No & Benefits & E.g., (only first author cited) & $\mathrm{f}$ & Benefits \\
\hline 1. & $\begin{array}{l}\text { Impacted positively on conceptual knowledge, higher- } \\
\text { order thinking skills, and design project activity }\end{array}$ & Fan (2015) & 1 & Cognitive \& Procedural/skills \\
\hline 2. & $\begin{array}{l}\text { Improved subject matter and pedagogical content } \\
\text { knowledge }\end{array}$ & Hynes (2012) & 1 & Cognitive \& Procedural/skills \\
\hline 3. & Improved achievement and creative attitude & Korur (2015) & 1 & Cognitive \& Procedural/skills \\
\hline 5. & Improved scientific knowledge and reasoning & Yu (2019); Wendell (2019) & 2 & Cognitive \& Procedural/skills \\
\hline 6. & Improved students' understanding and self-efficacy & Zhou (2017) & 1 & Cognitive \& Attitude \\
\hline 7. & Improved knowledge building and students' interest & Egbue (2015) & 1 & Cognitive \& Attitude \\
\hline 8. & Motivated students to write and communicate & Hertel (2017) & 1 & Attitude \& Procedural/skills \\
\hline 9. & Improved curiosity and scientific disciplines & Ward (2016) & 1 & Attitude \& Procedural/skills \\
\hline 10. & Improved attitudes and science content knowledge & Wendell (2013) & 1 & Attitude \& Procedural/skills \\
\hline 11. & Improved students' knowledge, attitudes, and practices & Siew (2016) & 1 & $\begin{array}{l}\text { Attitude, Procedural/skills, } \\
\text { and attitude }\end{array}$ \\
\hline & Total & & 11 & \\
\hline
\end{tabular}

characteristics of the content are one of the important parts in writing a literature review study.

The articles reviewed in this study were published from 2010 to 2020 . The span of 10 years was specifically chosen so that the results of this study are not out of date (still conforming to the current situation) and are suitable for use as a reference by stakeholders in the field of science education. The highest number of reviewed articles were published in 2016, and the lowest number was published in 2020. All chosen articles are of good quality because they are indexed by Scopus and WoS. The countries that implement the engineering design process in science education are still very few in number. The research approaches used are quantitative, qualitative, and mixed methods. The most used research approach was qualitative, and the least used approach was mixed methods. Most studies used a qualitative research approach because data collection from some of these studies usually employed one observation or interviews through video recordings. Based on the method of collecting the data, the researcher chose a research approach that was deemed more suitable, which was qualitative, compared to other research approaches. The results of this statement are in line with research in the engineering design process in science education, which mostly used a qualitative research approach (Johnston, Akarsu, Moore, \& Guzey, 2019; King \& English, 2016). Meanwhile, studies that use a mixed-method research approach mostly employed data collection in more than one manner, such as classroom observations, science tests, and surveys (Guzey, RingWhalen, Harwell, \& Peralta, 2017). In addition, Gunbatar (2018) also used a mixed-method in his research. In the study, data collection methods used two methods: the Chemistry achievement test and interviews. Furthermore, the engineering design process is implemented in science education of various educational stages (levels). The results of the analysis show that the implementation in the undergraduate/graduate level is still rather scarce compared to the elementary, middle school, and high school levels. Therefore, there are still many opportunities to seek research novelty from the implementation of the engineering design process at the university level.

This study analyzed the characteristics of the content based on the year of publication, type of publication, countries that implement the engineering design process, research approach, educational stage, and science content. The choice of content analysis was supported by several previous studies that examine the year of publication (Jayarajah, Saat, Rauf, \& Amnah, 2014; Martín-Páez, Aguilera, Perales-Palacios, \& Vílchez-González, 2019), the type of publication (Belland, Walker, Kim, \& Lefler, 2017; Çetin \& Demircan, 2018; Henderson, Beach \& Finkelstein, 2011; Jeong, Hmelo-Silver, \& Jo, 2019; Martín-Páez, Aguilera, PeralesPalacios, \& Vílchez-González, 2019), and the countries that implement it (Martín-Páez, Aguilera, PeralesPalacios, \& Vílchez-González, 2019; Reinhold, Holzberger, \& Seidel, 2018; Uzunboylu \& Özcan, 2019). Jayarajah, Saat, Rauf, and Amnah (2014) also claims that examining the research approach is important in the analysis of the general characteristics of the content. In addition, some previous studies also investigate the content based on the educational stage (Deveci \& Çepni, 2017; Martín-Páez, Aguilera, Perales-Palacios, \& Vílchez-González, 2019) and the science content (Arik \& Topçu, 2020). If a study analyzes content based on the year of publication, type of publication, countries that implement the engineering design process, research approach, educational stage, and science content, the results of the study can provide an overview for readers. Readers can judge whether the journals being analyzed are of high quality, up-to-date, and assess other important aspects.

This study also analyzed the distribution of research based on design projects and discussed topics when implementing the engineering design process in science education. The results show that the design projects varied based on the discussed topics. The distribution of research based on design projects and discussed topics 
discovered that the implementation of the engineering design process was found in Science, Physics, Biology, Chemistry, and the integration of science with other subjects. Some examples of research in the engineering design process in Science use bridge construction project to teach the topic of measurements to 58 middle school students (English, Hudson, \& Dawes, 2012), submarine building to teach the topic of fluid to 89 middle school students (Siew, Goh, \& Sulaiman, 2016), and musical instrument, door alarm, compost column, solar panel tracker were also used to teach the topic of energy and matter to 32 elementary school teachers (Capobianco, DeLisi, \& Radloff, 2018).

Some examples of research in the engineering design process in Physics design a wind turbine to teach the topic of energy (Bamberger \& Cahill, 2013), an optical instrument to teach the topic of mirror and lens (King \& English, 2016), and used free electrical energy to teach the topic of electricity and magnetism (Syukri, Halim, Mohtar, \& Soewarno, 2018). In addition, some studies related to the engineering process in Biology designed a simple hydroponic system to teach the topic of Plants (Crotty et al., 2017); explore cells, consider the relationship of the structure and function of DNA were also discussed to teach the topic of genetically modified organisms (GMOs) (Lie, Guzey, \& Moore, 2019). In Chemistry, the topic of climate change, energy use, and greenhouse gases utilized the project of airbag design and chemical reactions project (Chiu \& Linn, 2011). Furthermore, Hammack, Ivey, Utley, and High (2015) taught the topic of chemicals using an airplane design project, a popcorn challenge, and a rocket body attached to their film canisters. In addition to Science, Physics, Biology, and Chemistry, the engineering design process is also implemented in science that is integrated with other subjects. That said, projects at hand may utilize several subjects at once. The engineering design process for the integration of science with other subjects was designing a pinhole camera, a system to take aerial images, a wind turbine, robotic vehicles, and construction helmets. The aforementioned projects were used to teach the topic of power equations and energy transformation (Science) and converting between different units of measurement (Mathematics) (Berland \& Steingut, 2016). Moreover, Apedoe and Schunn (2013) taught the topic of Genetics (Biology), projectile motion (Physics), chemical energy (Chemistry) through the project of designing the earthquake task.

The result of this study also shows that the implementation of the engineering design process has its benefits in science education. The said benefits were classified into cognitive benefits, procedural benefits (skills benefits), attitudinal benefits, the combination of the three benefits. This result is in line with the previous study that found STEM approach in science education to have resulted in cognitive benefits, procedural benefits (skills benefits), and attitudinal benefits (Martín-Páez,
Aguilera, Perales-Palacios, \& Vílchez-González, 2019). The difference of this study from the aforementioned previous study lies in the classification of the benefits. The previous study divided the benefits into three, whereas this study divided the benefits into four aspects, adding the combination of cognitive, procedural (skills), and attitudinal benefits.

Several previous studies investigated that the cognitive benefits of the implementation of the engineering design process were that it improved students' content knowledge/students' achievement (Aydin-Gunbatar, Tarkin-Celikkiran, Kutucu, \& EkizKiran, 2018; Chao et al., 2017; Dankenbring \& Capobianco, 2016; Guzey, Ring-Whalen, Harwell, \& Peralta, 2017; Marulcu \& Barnett, 2013; Park, Park, \& Bates, 2016). Mesutoglu and Baran (2020) also claimed that the engineering design process improved science teachers' understanding. When it comes to procedural benefits (skills benefits), some researches stated that the engineering design process improved students' problem-solving skills (English, Hudson, \& Dawes, 2013; Syukri, Halim, Mohtar, \& Soewarno, 2018), students' ability in designing a project (Xie, 2018) as well as sophisticated discourse (McFadden \& Roehrig, 2018; Wendell, Wright, \& Paugh, 2017). Furthermore, attitudinal benefits were also found in the implementation of the engineering design process. The stated benefits include improving students' interest in STEM subjects and career (Shahali, Halim, Rasul, Osman, \& Zulkifeli, 2016), attitudes towards engineering (Lie, Guzey, \& Moore, 2019), and it impacted positively on students' perceptions of engineering and technology (Hammack, Ivey, Utley, \& High, 2015). To add, the engineering design process in science education may result in the combination of cognitive, procedural/skills, and attitudinal benefits. Fan and Yu (2015) claimed that the engineering design process improved students' achievement (cognitive benefits) and creative attitude (procedural/skills benefits). This finding is supported by another study asserting that the engineering design process improved scientific knowledge (cognitive benefits) and reasoning (procedural/skills benefits) (Yu, Wu, \& Fan, 2019; Wendell, Swenson, \& Dalvi, 2019). One research even found the combination of all three benefits: improved students' knowledge (cognitive benefits), attitude (attitudinal benefits), and practices (procedural/skills benefits) (Siew, Goh, \& Sulaiman, 2016). So, the benefits of the implementation of the engineering design process in science education include cognitive benefits, procedural (skills) benefits, attitudinal benefits, and a combination of the three benefits.

This research also has its strengths and weaknesses. The strength of this research is that the chosen journals are of high quality and up to date. This statement is supported by the fact that the selected articles were chosen from journals indexed by Scopus (Q1 and Q2) 
and the Web of Science (WoS) in the last ten years. The results of this study are very useful because topics and projects commonly used by previous researchers are elaborated. In addition, the results of this research can be useful for teachers, lecturers, or further researchers in order to implement the engineering design processes in science education or other fields. Meanwhile, the weakness of this research is that aspects related to how the stages of the engineering design process in science education have not been explained. However, research related to stages of the engineering design process in science education can be explained in further research.

\section{CONCLUSIONS}

Currently, the reform of science education is to integrate science learning with the engineering design process. However, there are still challenges met in its implementation. The implementation is found to still be rather inconsistent. Most science teachers are still too unfamiliar with the engineering design process to be able to implement it in their science teaching. Therefore, a literature review study is important to be carried out. This study analyzed the characteristics of the content based on the year of publication, type of publication, countries that implement the engineering design process, research approach, educational stage, and science content. The result of the study shows that there were 48 articles chosen for review published from 2010 to 2020. All chosen articles are of good quality because they are indexed by Scopus and WoS. The countries that implement the engineering design process in science education are the United States of America (USA), Australia, Taiwan, Turkey, Malaysia, Denmark, and Indonesia. The most used research approach was qualitative, and the least used approach was mixed methods. Moreover, the engineering design process is implemented in science education of various educational stages (level). However, the implementation in the undergraduate/graduate level is still rather scarce. The engineering design process was found to be implemented in Science, Physics, Biology, Chemistry, and the integration of science with other subjects. This study also analyzed the distribution of research based on design projects and discussed topics when implementing the engineering design process in science education. The results show that the choice of projects used in implementing the engineering design process varied based on the discussed topics. Additionally, the implementation of the engineering design process has its benefits in science education. The benefits include cognitive benefits, procedural benefits (skills benefits), attitudinal benefits, and the combination of cognitive, procedural (skills), and attitudinal. The engineering design process is considered a new trend in the current reform of science education. Thus, the results of this study can be used as a reference for all stakeholders involved in science education, especially teachers, lecturers, or future researchers. In addition, the engineering design process can be used as an alternative learning approach in science education. The gap for future research is that we have not found any study that implements the engineering design process in the subject of integrated science with preservice science teachers as subjects. Therefore, we recommend the engineering design process to be implemented in science education with projects and topics that have yet to be discussed by previous researchers. Also, research related to stages of the engineering design process in science education can be explained in further research.

\section{REFERENCES}

Apedoe, X. S., \& Schunn, C. D. (2013). Strategies for success: uncovering what makes students successful in design and learning. Instructional Science, 41(4), 773-791. https://doi.org/10.1007/ s11251-012-9251-4

Arık, M., \& Topçu, M. S. (2020). Implementation of engineering design process in the K-12 science classrooms: trends and issues. Research in Science Education, 1-23. https://doi.org/10.1007/s11165019-09912-x

Atman, C. J., Adams, R. S., Cardella, M. E., Turns, J., Mosborg, S., \& Saleem, J. (2007). Engineering design processes: a comparison of students and expert practitioners. Journal of Engineering Education, 96(4), 359-379. https:/ / doi.org/10.1002/ j.2168-9830.2007.tb00945.x

Aydin-Gunbatar, S., Tarkin-Celikkiran, A., Kutucu, E. S., \& Ekiz-Kiran, B. (2018). The influence of a designbased elective STEM course on preservice chemistry teachers' content knowledge, STEM conceptions, and engineering views. Chemistry Education Research and Practice, 19(3), 954-972. https://doi.org/10.1039/c8rp00128f

Bamberger, Y. M., \& Cahill, C. S. (2013). Teaching design in middle-school: Instructors' concerns and scaffolding strategies. Journal of Science Education and Technology, 22(2), 171-185. https://doi.org/ 10.1007/s10956-012-9384-x

Banko, W., Grant, M. L., Jabot, M. E., McCormack, A. J., \& O'Brien, T. (2013). Science for the next generation.

Bennett, J., Lubben, F., Hogarth, S., \& Campbell, B. (2005). Systematic reviews of research in science education: rigour or rigidity?. International Journal of Science Education, 27(4), 387-406. https://doi.org/10.1080/0950069042000323719

Berland, L. K., Martin, T. H., Ko, P., Peacock, S. B., Rudolph, J. J., \& Golubski, C. (2013). Student learning in challenge-based engineering curricula. Journal of Pre-College Engineering Education Research (J-PEER), 3(1), 53-64. https://doi.org/10.7771/ 2157-9288.1080 
Berland, L., Steingut, R., \& Ko, P. (2014). High school student perceptions of the utility of the engineering design process: creating opportunities to engage in engineering practices and apply math and science content. Journal of Science Education and Technology, 23(6), 705-720. https://doi.org/10.1007/s10956014-9498-4

Berland, L. K., \& Steingut, R. (2016). Explaining variation in student efforts towards using math and science knowledge in engineering contexts. International Journal of Science Education, 38(18), 2742-2761. https:/ / doi.org/10.1080/09500693.2016.1260179

Belland, B. R., Walker, A. E., Kim, N. J., \& Lefler, M. (2017). Synthesizing results from empirical research on computer-based scaffolding in STEM education: A meta-analysis. Review of Educational Research, 87(2), 309-344. https://doi.org/10.3102/00346543 16670999

Borrego, M., Foster, M. J., \& Froyd, J. E. (2014). Systematic literature reviews in engineering education and other developing interdisciplinary fields. Journal of Engineering Education, 103(1), 45-76. https:// doi.org/10.1002/jee.20038

Capobianco, B. M. (2011). Exploring a science teacher's uncertainty with integrating engineering design: An action research study. Journal of Science Teacher Education, 22(7), 645-660. https:/ / doi.org/10.1007/ s10972-010-9203-2

Capobianco, B.M., Yu, J.H. \& French, B.F. (2014). Effects of engineering design-based science on elementary school science students' engineering identity development across gender and grade. Res Sci Educ 45, 275-292. https://doi.org/10.1007/s11165-0149422-1

Capobianco, B. M., DeLisi, J., \& Radloff, J. (2018). Characterizing elementary teachers' enactment of high-leverage practices through engineering design-based science instruction. Science Education, 102(2), 342-376. https:/ / doi.org/10.1002/ sce.21325

Çetin, M., \& Demircan, H. Ö. (2018). Empowering technology and engineering for STEM education through programming robots: a systematic literature review. Early Child Development and Care, $1-13$.

https:/ / doi.org/10.1080/03004430.2018.1534844

Chao, J., Xie, C., Nourian, S., Chen, G., Bailey, S., Goldstein, M. H., ... \& Tutwiler, M. S. (2017). Bridging the design-science gap with tools: Science learning and design behaviors in a simulated environment for engineering design. Journal of Research in Science Teaching, 54(8), 1049-1096. https:/ / doi.org/10.1002/tea.21398

Chase, C. C., Malkiewich, L., \& S Kumar, A. (2019). Learning to notice science concepts in engineering activities and transfer situations. Science Education, 103(2), 440-471. https:/ / doi.org/10.1002/ sce.21496

Chiu, J. L., \& Linn, M. C. (2011). Knowledge integration and wise engineering. Journal of Pre-College Engineering Education Research (J-PEER), 1(1), 1-14. https:/ / doi.org/10.7771/2157-9288.1026

Crotty, E. A., Guzey, S. S., Roehrig, G. H., Glancy, A. W., Ring-Whalen, E. A., \& Moore, T. J. (2017). Approaches to integrating engineering in STEM units and student achievement gains. Journal of PreCollege Engineering Education Research (J-PEER), 7(2), 1-14. https:/ / doi.org/10.7771/2157-9288.1148

Dankenbring, C., \& Capobianco, B. M. (2016). Examining elementary school students' mental models of sunearth relationships as a result of engaging in engineering design. International Journal of Science and Mathematics Education, 14(5), 825-845. https:/ / doi.org/10.1007/s10763-015-9626-5

Deveci, İ., \& Çepni, S. (2017). Studies conducted on entrepreneurship in science education: thematic review of research. Journal of Turkish Science Education (TUSED), 14(4). 126-143. Retrieved from http:/ / tused.org/index.php/tused/article/view / 178

Dohn, N. B. (2013). Situational interest in engineering design activities. International Journal of Science Education, 35(12), 2057-2078. https://doi.org/ 10.1080/09500693.2012.757670

Dutson, A. J., Todd, R. H., Magleby, S. P., \& Sorensen, C. D. (1997). A review of literature on teaching engineering design through project-oriented capstone courses. Journal of Engineering Education, 86(1), 17-28. https://doi.org/10.1002/j.21689830.1997.tb00260.x

Egbue, O., Long, S., \& Ng, E. H. (2015). Charge it! Translating electric vehicle research results to engage 7 th and 8 th grade girls. Journal of science education and technology, 24(5), 663-670. https: / / doi.org/10.1007/s10956-015-9555-7

English, L. D., Hudson, P. B., \& Dawes, L. (2012). Engineering design processes in seventh-grade classrooms: Bridging the engineering education gap. European Journal of Engineering Education, 37(5), 436-447.

https:/ / doi.org/10.1080/03043797.2012.708721

English, L. D., Hudson, P. B., \& Dawes, L. A. (2013). Engineering based problem solving in the middle school: Design and construction with simple machines. Journal of Pre-College Engineering Education Research, 3(2), 1-13. https://doi.org/ 10.7771/2157-9288.1081

English, L. D., King, D., \& Smeed, J. (2016). Advancing integrated STEM learning through engineering design: Sixth-grade students' design and construction of earthquake resistant buildings. The 
Journal of Educational Research, 110(3), 255-271. https:// doi.org/10.1080/00220671.2016.1264053

Fan, S. C., \& Yu, K. C. (2015). How an integrative STEM curriculum can benefit students in engineering design practices. International Journal of Technology and Design Education, 27(1), 107-129. https:// doi.org/10.1007/s10798-015-9328-x

Guzey, S. S., Harwell, M., Moreno, M., Peralta, Y., \& Moore, T. J. (2016). The impact of design-based STEM integration curricula on student achievement in engineering, science, and mathematics. Journal of Science Education and Technology, 26(2), 207-222. https://doi.org/ 10.1007 / s10956-016-9673-x

Guzey, S. S., Moore, T. J., Harwell, M., \& Moreno, M. (2016). STEM integration in middle school life science: Student learning and attitudes. Journal of Science Education and Technology, 25(4), 550-560. https:// doi.org/10.1007/s10956-016-9612-x

Guzey, S. S., Ring-Whalen, E. A., Harwell, M., \& Peralta, Y. (2017). Life STEM: A case study of life science learning through engineering design. International Journal of Science and Mathematics Education, 17(1), 23-42. https:/ / doi.org/10.1007/s10763-017-9860-0

Hammack, R., Ivey, T. A., Utley, J., \& High, K. A. (2015). Effect of an engineering camp on students' perceptions of engineering and technology. Journal of Pre-College Engineering Education Research (JPEER), 5(2), 10-21. https://doi.org/10.7771/21579288.1102

Henderson, C., Beach, A., \& Finkelstein, N. (2011). Facilitating change in undergraduate STEM instructional practices: An analytic review of the literature. Journal of research in science teaching, 48(8), 952-984. https:/ / doi.org/10.1002/tea.20439

Hertel, J. D., Cunningham, C. M., \& Kelly, G. J. (2017). The roles of engineering notebooks in shaping elementary engineering student discourse and practice. International Journal of Science Education, 39(9),

1194-1217.

https:/ / doi.org/10.1080/09500693.2017.1317864

Hynes, M. M. (2012). Middle-school teachers' understanding and teaching of the engineering design process: A look at subject matter and pedagogical content knowledge. International journal of technology and design education, 22(3), 345360. https:// doi.org/10.1007/s10798-010-9142-4

Jayarajah, K., Saat, R. M., Rauf, A., \& Amnah, R. (2014). A Review of Science, Technology, Engineering \& Mathematics (STEM) Education Research from 1999-2013: A Malaysian Perspective. Eurasia Journal of Mathematics, Science \& Technology Education, 10(3). $155-163$.

https:/ / doi.org/10.12973/eurasia.2014.1072a
Jeong, H., Hmelo-Silver, C. E., \& Jo, K. (2019). Ten years of computer-supported collaborative learning: a meta-analysis of CSCL in STEM education during 2005-2014. Educational Research Review, 28, 100284. https:/ / doi.org/10.1016/j.edurev.2019.100284

Johnston, A. C., Akarsu, M., Moore, T. J., \& Guzey, S. S. (2019). Engineering as the integrator: A case study of one middle school science teacher's talk. Journal of Engineering Education, 108(3), 418-440. https:/ / doi.org/10.1002/jee.20286

King, D., \& English, L. D. (2016). Engineering design in the primary school: Applying STEM concepts to build an optical instrument. International Journal of Science Education, 38(18), 2762-2794. https:/ / doi.org/10.1080/09500693.2016.1262567

Kim, E., Oliver, J. S., \& Kim, Y. A. (2019). Engineering design and the development of knowledge for teaching among preservice science teachers. School Science and Mathematics, 119(1), 24-34. https:// doi.org/10.1111/ssm.12313

Korur, F., Efe, G., Erdogan, F., \& Tunç, B. (2015). Effects of toy crane design-based learning on simple machines. International Journal of Science and Mathematics Education, 15(2), 251-271. https:// doi.org/10.1007/s10763-015-9688-4

Lammi, M., Denson, C., \& Asunda, P. (2018). Search and review of the literature on engineering design challenges in secondary school settings. Journal of Pre-College Engineering Education Research (J-PEER), 8(2), 49-66. https://doi.org/10.7771/21579288.1172

Lie, R., Aranda, M. L., Guzey, S. S., \& Moore, T. J. (2019). Students' views of design in an engineering designbased science curricular unit. Research in Science Education, 1-21. https://doi.org/10.1007/s11165018-9813-9

Lie, R., Guzey, S. S., \& Moore, T. J. (2019). Implementing engineering in diverse upper elementary and middle school science classrooms: Student learning and attitudes. Journal of Science Education and Technology, 28(2), 104-117. https:/ / doi.org/10.1007 / s10956-018-9751-3

Lin, K. Y., Hsiao, H. S., Chang, Y. S., Chien, Y. H. \& Wu, Y. T. (2018). The effectiveness of using 3D printing technology in STEM project-based learning activities. EURASIA Journal of Mathematics, Science and Technology Education, 14(12), 1-13. https:/ / doi.org/10.29333/ejmste/97189

Maeng, J. L., Whitworth, B. A., Gonczi, A. L., Navy, S. L., \& Wheeler, L. B. (2017). Elementary science teachers' integration of engineering design into science instruction: results from a randomised controlled trial. International Journal of Science Education, 39(11), 1529-1548. https://doi.org/ 10.1080/09500693.2017.1340688 
Martín-Páez, T., Aguilera, D., Perales-Palacios, F. J., \& Vílchez-González, J. M. (2019). What are we talking about when we talk about STEM education? A review of the literature. Science Education. 1-24. https:// doi.org/10.1002/sce.21522

Marulcu, I., \& Barnett, M. (2013). Fifth graders' learning about simple machines through engineering design-based instruction using LEGO $^{\mathrm{TM}}$ materials. Research in Science Education, 43(5), 1825-1850. https: / / doi.org/10.1007/s11165-012-9335-9

McFadden, J., \& Roehrig, G. (2018). Engineering design in the elementary science classroom: supporting student discourse during an engineering design challenge. International Journal of Technology and Design Education, 29(2), 231-262. https://doi.org/ 10.1007/s10798-018-9444-5

Mesutoglu, C., \& Baran, E. (2020). Examining the development of middle school science teachers' understanding of engineering design process. International Journal of Science and Mathematics Education, 1-21. https://doi.org/10.1007/s10763019-10041-0

Nurtanto, M., Pardjono, P., Widarto, W., \& Ramdani, S. D. (2020). The effect of STEM-EDP in professional learning on automotive engineering competence in vocational high school. Journal for the Education of Gifted Young Scientists, 8(2), 633-649. https:/ / doi.org/10.17478/jegys.645047

Ogunkola, B. J., \& Samuel, D. (2011). Science teachers' and students' perceived difficult topics in the integrated science curriculum of lower secondary schools in Barbados. World Journal of Education, 1(2), 17-29. https:/ / doi.org/10.5430/wje.v1n2p17

Park, D. Y., Park, M. H., \& Bates, A. B. (2016). Exploring young children's understanding about the concept of volume through engineering design in a STEM activity: A case study. International Journal of Science and Mathematics Education, 16(2), 275-294. https: / / doi.org/10.1007/s10763-016-9776-0

Petticrew, M., \& Roberts, H. (2008). Systematic reviews in the social sciences: A practical guide. John Wiley \& Sons.

Pleasants, J., Olson, J. K., \& De La Cruz, I. (2020). Accuracy of elementary teachers' representations of the projects and processes of engineering: results of a professional development program. Journal of Science Teacher Education, 1-22. https:/ / doi.org/10.1080/1046560X.2019.1709295

Reinhold, S., Holzberger, D., \& Seidel, T. (2018). Encouraging a career in science: a research review of secondary schools' effects on students' STEM orientation. Studies in Science Education, 54(1), 69103.

https:/ / doi.org/10.1080/03057267.2018.1442900
Schnittka, C., \& Bell, R. (2011). Engineering design and conceptual change in Science: Addressing thermal energy and heat transfer in eighth grade. International Journal of Science Education, 33(13), 1861-1887.https:/ / doi.org/10.1080/09500693.2010. 529177

Schnittka, C. G. (2012). Engineering education in the science classroom: A case study of one teacher's disparate approach with ability-tracked classrooms. Journal of Pre-College Engineering Education Research (J-PEER), 2(1), 35-48. https:/ / doi.org/10.5703/1288284314654

Shahali, E. H. M., Halim, L., Rasul, M. S., Osman, K., \& Zulkifeli, M. A. (2016). STEM learning through engineering design: Impact on middle secondary students' interest towards STEM. EURASIA Journal of Mathematics, Science and Technology Education, 13(5), 1189-1211. https://doi.org/10.12973/ eurasia.2017.00667a

Siew, N. M., Goh, H., \& Sulaiman, F. (2016). Integrating STEM in an engineering design process: the learning experience of rural secondary school students in an outreach challenge program. Journal of Baltic Science Education, 15(4), 477-493. http:/ / www.scientiasocialis.lt/jbse/?q=node/518

Sun, D., Wang, Z. H., Xie, W. T., \& Boon, C. C. (2014). Status of integrated science instruction in junior secondary schools of China: An exploratory study. International Journal of Science Education, 36(5), 808838.

https:/ / doi.org/10.1080/09500693.2013.829254

Syukri, M., Halim, L., Mohtar, L. E., \& Soewarno, S. (2018). The impact of engineering design process in teaching and learning to enhance students' science problem-solving skills. Jurnal Pendidikan IPA Indonesia, 7(1), 66-75. https://doi.org/10.15294/ jpii.v7i1.12297

Uzunboylu, H., \& Özcan, D. (2019). Teaching methods used in special education: A content analysis study. International Journal of Cognitive Research in Science, Engineering, and Education, 7(2), 99-107. https:/ / doi.org/10.5937/IJCRSEE1902099U

Valtorta, C. G., \& Berland, L. K. (2015). Math, science, and engineering integration in a high school engineering course: A qualitative study. Journal of Pre-College Engineering Education Research (J-PEER), 5(1),15-29.https:/ / doi.org/10.7771/2157-9288.1087

Ward, L., Lyden, S., Fitzallen, N., \& León de la Barra, B. (2016). Using engineering activities to engage middle school students in physics and biology. Australasian Journal of Engineering Education, 20(2), 145-156.

https: / / doi.org/10.1080/22054952.2015.1130092

Wendell, K. B., \& Lee, H. S. (2010). Elementary students' learning of materials science practices through 
instruction based on engineering design tasks. Journal of Science Education and Technology, 19(6), 580-601. https://doi.org/10.1007/s10956-0109225-8

Wendell, K.B., \& Rogers, C. (2013). Engineering designbased science, science content performance, and science attitudes in elementary school. Journal of Engineering Education, 102(4), 513-540. https://doi.org/10.1002/jee.20026

Wendell, K. B., Wright, C. G., \& Paugh, P. (2017). Reflective decision-making in elementary students' engineering design. Journal of Engineering Education, 106(3), 356-397. https:// doi.org/10.1002/jee.20173

Wendell, K. B., Swenson, J. E., \& Dalvi, T. S. (2019). Epistemological framing and novice elementary teachers' approaches to learning and teaching engineering design. Journal of Research in Science Teaching, 56(7), 956-982. https://doi.org/10.1002/ tea. 21541

Winarno, N., Rusdiana, D., Riandi, R., Susilowati, E., \& Afifah, R. M. A.(2020). Implementation of Integrated Science Curriculum: A Critical Review of the Literature. Journal for the Education of Gifted Young Scientists, 8(2), 795-815. https://doi.org/ $10.17478 /$ jegys.675722
Xie, C., Schimpf, C., Chao, J., Nourian, S., \& Massicotte, J. (2018). Learning and teaching engineering design through modeling and simulation on a CAD platform. Computer Applications in Engineering Education, 26(4), 824-840. https://doi.org/10.1002/ cae. 21920

Yu, K. C., Wu, P. H., \& Fan, S. C. (2019). Structural relationships among high school students' scientific knowledge, critical thinking, engineering design process, and design product. International Journal of Science and Mathematics Education, 1-22. https://doi.org/10.1007/s10763-019-10007-2

Zhang, H., \& He, H. (2012). Student perceptions of the integrated 'science education'major in some Chinese universities. International Journal of Science Education, 34(13), 1991-2013. https://doi.org/ 10.1080/09500693.2012.709332

Zhou, N., Pereira, N. L., George, T. T., Alperovich, J., Booth, J., Chandrasegaran, S., ... Ramani, K. (2017). The influence of toy design activities on middle school students' understanding of the engineering design processes. Journal of Science Education and Technology, 26(5), 481-493. https:// doi.org/10.1007 / s10956-017-9693-1

\section{http://www.ejmste.com}

